\title{
Authoritarian governmentality through the global city: contradictions in the political ecology of historical capitalism
}

\section{John Welsh}

To cite this article: John Welsh (2017) Authoritarian governmentality through the global city: contradictions in the political ecology of historical capitalism, Contemporary Politics, 23:4, 446-468, DOI: $10.1080 / 13569775.2017 .1334285$

To link to this article: http://dx.doi.org/10.1080/13569775.2017.1334285

曲 Published online: 30 May 2017.

Submit your article to this journal

Џ Article views: 61

Q View related articles $\square$

View Crossmark data ¿ 


\title{
Authoritarian governmentality through the global city: contradictions in the political ecology of historical capitalism
}

\author{
John Welsh (1) \\ Department of Political and Economic Studies, University of Helsinki, Helsinki, Finland
}

\begin{abstract}
Over 30 years of strategic reconfiguration, Global Cities have proven themselves productive of metropolitan oligarchies of various hues that dominate the territories of their respective states. Set against the 'ecological contradictions' of historical capitalism, the article presents the Global City formation as a historically particular postdisciplinary technique in the capitalist world-system bound into the ecological contradictions of that system entering into a period of chronic crisis in the twenty-first century. This idiomatic technique is conceptualised in geo-historical terms as a distinct 'Geotechnic' modulation of control, through which the Global City is constituted as a geo-machinic assemblage in the historical technics of capitalist civilisation. Through a critical human geography, marxist political economy, and post-structuralist governmetnality studies, the adequacy of the Global Cities research agenda is challenged, and the emerging role of the World-City Archipelago in historical capitalism explored. In a constructive critique of Wolfgang Streeck's 'end of capitalism' thesis, the aim is to present the 'geotechnic city' as an emergent modality of global discipline in historical capitalism, whereby the latter's strategic contradictions are contained, resolved, displaced, sublated through a particular genre of spatio-temporal fix, and the future of the capitalist totality is secured through a new political idiom of metropolitan oligarchy.
\end{abstract}

\section{KEYWORDS}

Capitalist world-system; global city; urban assemblage; world-cities archipelago; Geotechnics; urban sociology

\section{Global cities: capitalist oligarchy and ecological contradiction}

Wolfgang Streeck has recently attempted to place before us a capitalism in terminal decline $(2014,2016)$. By positing a Polanyian dialectic immanent to 'democratic capitalism', that of marginal productivity economics and the 'collective choices of democratic politics' (Streeck, 2011, p. 7), he has opened up a space for hope and radical-critical action in the context of advanced capitalism. I do not want to close off this interstitial potential, but I do want to consider how the totality of historical capitalism is not only a versatile spatio-temporal system and adept at arriving upon the means of its own survival and reproduction, but how it is also historically and logically tendential not to democratic form in this dialectic, but rather oligarchic form. In a given constellation of spatio-temporal forces in history, it is the oligarchic form that often arises to facilitate this survival, with 
consequent destruction and retrogression visited upon a swelling biopolitical mass of broken and policed humanity. To do this I am going to talk about capitalism in two ways simultaneously: as a political technology and as a topology. This means inserting a certain geographical inflection to Streeck's thesis, in order to place the analysis of capitalism's survival into a deeper historical and ecological context. The implication of this is an elongation of his 'longer term' view (Streeck, 2011, p. 5), into an even longer term view, with the consequent insight that capitalism's contradictions are being drawn out by the strategic reconfiguration of social relations into a particularly metropolitan urban form of oligarchic political power.

Since the end of the 1970s, there has been a fundamental shift in the balance of wealth and power across the core of the Capitalist World-System (CWS) manifest in 'Neoliberalization', the cultural re-articulation of a revanchist quasi-aristocracy, the political alienation of urban swathes of the demographic map, intensified surveillance and police power, massive concentration of capital accumulation positionalities, the contrivance of enforced scarcity, and tighter dispositioning and control over access to urban spaces and motion through privatisation, enclosure and canalisation and other techniques of the 'police power' (Foucault, 2002a, 2007; Rancière, 1999, 2015). This has entailed the emergence of an identifiable set of social and political trends discernable across the landscape of Global Cities (GCs): concentration, enclosure, privatisation, intensified arborescence, stratification, social cleansing, oligarchy, enforced scarcity, urban spectacle, rent-seeking, material waste, tribute-collection, conspicuous consumption, surplus value capture, and an almost byzantine appetite for luxury and ostentation tellingly reminiscent of the Roaring 20s. These trends are unfolding through a thematic isomorph that runs right through almost all strategic geo-social transformations across the capitalist core states, resulting in the establishment of a species of global metropolitan oligarchy. ${ }^{1}$

Conspicuous features of this urban trend within the core states are: (1) mounting labour surpluses locally; (2) chronic contradiction between use-/exchange-values in housing; (3) food/energy production contradictions; (4) ecological damage from resource consumption; (5) hugely uneven enjoyment of productivity gains; (6) the demographic reproduction of workforces and immigration. Evidently, the global city as an increasingly dominant political, cultural, and economic form in the capitalist core states is closely bound historically into the generalised response to the emergence of ecological contradictions in the mode of production, consumption, distribution, and exchange that is the CWS.

Profound social and political transformations that are productive of metropolitan urban oligarchy have been realised principally through the growing pre-eminence of Global Cities in their relations both with their respective 'hinterlands' and with other cities across the World-Cities Archipelago (WCA). What is of supreme importance is that these developments in the Global City have unfolded through a number of temporalities all at once, and unevenly across the capitalist world-system as one looks at individual Global Cities. These temporalities overlay one another, coexist in the same space, and are present to varying degrees of intensity in all Global Cities. But one thing that these temporalities have in common is that they are all affected responses to the contradiction-ridden dynamic of capital accumulation and its various regimes in the 'logic of territory' that controls, displaces, and activates them.

The most immediate temporality of development is the Austerity City, whose tempos emerged in the wake of the 2007 financial crash and subsequent 'Austerity politics'. It is 
the city of public cuts, rapid enclosure, conspicuous deployment of capital into the built environment, intensified police repression. Another temporality is that of the Neoliberal City - more familiar to critical scholarship - characterised by the emergence of Global Cities themselves, financialisation, urban concentrations of capital, the imposition of metropolitan command over capital disbursements, rising wealth asymmetries, debtdriven capitalist reproduction, etc. Other temporalities might include the Post-Industrial City, the Rentier City, the Neo-Imperial City or perhaps the Networked City. Another temporality that has been a little neglected in the literature, however, is what I will call the Geotechnic City. This is a longer, and perhaps deeper, temporality in advanced capitalism and which is realised in the emergence of Global Cities bound into the ecological contradictions of historical capitalism.

Global cities are restructuring the 'decentered urban field' of Sharpe and Wallock's 'third phase' cities of the late twentieth century (1987, pp. 9-12), and re-inscribing a determinate dynamic to the city form. The impression of an 'undifferentiated extension ... and eventual obliteration of the city's distinctive character' (1987, p. 32), which is connoted by the term 'dispersed urban field', seems increasingly at odds with an iterative form and logic in the global city that is hard to ignore. The 1980s de-territorialisation of the post-war cities of Keynesianism, Fordist production, welfare-state capitalism, and mass consumerism, engendered the contemporary sense of a disintegrating, dispersed, and 'illegible' city. I argue that amidst the re-territorializations of the capitalist city made starkly manifest by the 2010s, this illegibility is no longer so defining a quality of the global city. What we have to do is to identify and explain this transformative dynamic of reconfiguration, illuminate its contours, adumbrate its logic, identify its purpose in a broader rationality and amidst contemporary social forces. It is a matter of the 'quest for urban legibility' (Sharpe \& Wallock, 1987, pp. 17, 36), and my particular answer lies in the ecological contradictions of historical capitalism. The aim is to reverse those 'doubts about whether the contemporary city has any underlying logic at all' (1987, p. 24), and to say something about what Engels referred to as the 'deep structure' of the capitalist city between accident and design, contingency and necessity.

Global Cities research emerged in the 1990s (Sassen, 2001), principally out of the earlier notion of 'World Cities' (Friedmann \& Wolff, 1982), and has been important in drawing attention to the rise of the global city form in the world-system. The fundamental problem with the Global Cities literature is its assumption of the global city as a post-industrial site of production and exchange, rather than consumption and distribution, and the consequent preoccupation with locating and identifying this production (i.e. 'producer services'). As a result, the unproductive character of the global city is missed, and the strategic reason for its emergence in the longue durée of historical capitalism left unexplained. Rightly enough, financialisation has taken centre stage in the Global Cities research agenda, but the key problem with the understanding of financialisation in the Global Cities literature is that it is restricted in scope to networks between global cities (Sassen, 2002), and to a rather unimaginative and conventional notion of the money-form bereft of territorial and geographical consideration. By re-inserting a territorial dimension, the command and control of the global city in the CWS can be perceived, and a more critical, versatile, and contemporaneously explanatory perspective on the global city can be derived. Lastly, Global Cities research has inadequately linked financialisation and the emergence of the global city form to the strategic contradictions of historical capitalism 
by omitting consideration of its material connection to the social metabolism. It is to these contradictions that I want to turn, as a means of understanding the historically emergent role of the global city form as a governmental assemblage in the survival of capitalism in terms of global ecology.

\section{Metro oligarchy: the asymmetries of capitalist governmentality}

In his recent book Seventeen Contradictions and the End of Capitalism (2015), David Harvey discusses a number of dynamic contradictions in the capitalist mode of production. Some of these contradictions ought properly to be considered strategic components of those 'converging crises' - principally in food, energy, and finance - that seem increasingly to define our epoch (George, 2010; McMichael, 2012; Moore, 2015, pp. 2, 40, 112). Harvey's Contradictions 15 and 16, two of the three so-called 'Dangerous Contradictions', relate to 'endless compound growth' and 'capitalism's relation to nature', respectively. These are 'ecological contradictions' that, properly speaking, concern neither homo faber nor homo oeconomicus, but 'species man' in the terminology of Marx's anthropology, and are thus of profound, world-historic significance for the condition of human life in the remainder of the century before us.

Global finance-capitalism appears to be entering a phase in which the $3 \%$ annual compound growth necessary to its continued reproduction will be ever more elusive a goal and illusive a reality (Harvey, 2010a, pp. 27-28, 227-228). This is occasioning a retreat in the core states from a macroeconomic situation where capital value and surplus is realised through 'expanded production' (Harvey, 2003, p. 57), and into an inversion of the historic 'frontier' of capital (Moore, 2015, pp. 67-68). We are to be confronted rather, by a kind of zero-sum political economy, where the purposive annihilation of capitals and the constant internalisation of limits become axiomatic, and where predation and 'accumulation-by-dispossession' become the principal tactics in a perpetual low-growth environment incapable of solving the ongoing crises of capital accumulation at the level of the totality. In a state like Britain, for example, where low productivity solutions to accumulation crises have become almost a national pastime, these strategies will have a nigh on caricatured place in the twenty-first century social experience. This new logic will likely necessitate a deepening of the existing tendency toward oligarchic and rent-seeking power-political structures (Zizek, 2012a), as well as the concomitant authoritarian rationalities and apparatuses that 'may be the most "effective" means toward development of advanced capitalist institutions and social forms' (Aronowitz, 1981, p. xxii).

The most salient question that then arises for the global city is thus: what can its various historical and geographical particularities of re-configuration, over the succeeding decades, indicate about how our spatio-temporal contradictions will be contained, resolved, realised, displaced and disbursed, against a global backdrop of capitalist social relations in molecular and molar crisis and reconfiguration?

As an 'ecological totality' that perpetually expands and contracts via spatio-temporal displacement (Harvey, 2010b, p. 196), capitalist reproduction can plausibly continue indefinitely (Harvey, 2015, p. 220). The role of the global city in the reconfiguration of this capitalist world-system then becomes an enabling socio-geographic structural device for realising, through the unique intensities of its form, those necessary spatio-temporal fixes on the grandest scale of historical capitalism that facilitate continuous strategic 
global displacement through the mechanisms of 'switching crises' (Harvey, 2006, pp. 428429; 2010a, p. 93). This will entail innumerable, but systematic and identifiable, asymmetries in the reproduction of capital, most likely in the form of devastating local retreats of capital at various thresholds of transcendence (liquidation of organised labour, destruction of built environments, provincial de-industrialization, relocation of production regimes, neglected local infrastructures, etc.). There is an increasingly limited scope for the conventional disciplining and reboot device of war in the global regime of accumulation, unless it is war waged within a polity upon its own citizens. It therefore seems that the requisite grand reconfiguration in the spatio-temporal regime of capital accumulation and reproduction will require a new geographic logic and apparatus through which an effective social architecture of fixity and flow can be actualised across the world and an appropriate physiological tempo of urban geography established. I argue that the global city with its awesome dispositional and pastoral power over extensive populations constitutes a strategic device executant of this logic. If the institutional 'armatures' of the disciplinary power germane to the industrial age are already in crisis (Deleuze, 1992), then a new governmental apparatus of control with pan-global scope will likely emerge.

Different responses to crises in capitalist governmentality are possible. Urban oligarchy is what has unfolded implicit in the prevailing Liberal logic of global capital. The twentyfirst century is said to be the 'Century of the City'. 2007 saw the historical tipping point whereby more than half of the Earth's population now live in urban agglomerations (United Nations Population Fund (UNFPA), 2007), and these of increasing size. This figure seems set to rise to at least $66 \%$ by 2050 (United Nations, Department of Economic and Social Affairs, Population Division, 2014). The trend toward global supremacy of the urban form - or 'urban field' (Sharpe \& Wallock, 1987) - must surely have profound implications for the materiality of human life, as well as for the urban imaginary, forms of political control, and the terms of urban association. We must consider what political effects for urban life are implicated in this trend. I argue that it is in the historical emergence of a particular configuration of cities in this generalised 'urban field' that the political geography of oligarchic power is being realised, and the key strategic apparatus of global governmental power is to find expression.

The fundamental aim here is to counter the celebratory imaginary that today suffuses the common presentation of the twenty-first century Global City in Liberal apologetics. The implicit Fable of the Bees inspired by Liberal ideology sees the great city as a grumbling hive of industriousness, creativity, peace, freedom, felicity, and sensuous self-realization. However, a glance at the history of the city form could just as easily conjure a vocabulary of slavery, confinement, brutality, strife, and extremely intimate social stratification (Anderson, 1978, pp. 21-22; Long, 1972, p. 26). It is the historically contingent form, in which social forces of historical necessity are met, that is decisive. In what direction will the 'Century of the City' take us, or in what pattern of ambiguities and contradictions will we potentially find ourselves? How might the city come to emplace a wider global 'system of rule' in terms of the twenty-first century ecological crises (Ruggie, 1993, p. 168)? We must follow Foucault's governmental question of 'how is one to conceive of both the organization of a city and the construction of a collective infrastructure' (Foucault, 2002c, p. 349)? For 'cities, with the problems that they raised, and the particular forms that they took, served as the models for the governmental rationality that was to apply to the whole territory ... the model of the city became the matrix for the regulation 
that applied to a whole state' (Foucault, 2002c, p. 351). We must be in no doubt that the fate of the twenty-first century city effects us all in the most profound way.

But the imperative collectively to apply human reason to the resolution of dangerous ecological contradictions in the global mode of production runs up against a crucial problem. It is the problem of collective human agency. If we cannot 'frame a comprehensive scheme of ends' amongst peoples based upon collective 'evaluation' of civilizational circumstances (Mumford, 1955, pp. 379, 282), to halt the destruction of the biosphere, and if millenarian crisis will not force a common programme of directed transformation of our behaviour as a species, how then will the mechanism resolving these historic contradictions come into being, whether from the commanding heights or from within the complex depths and details of the social? That such a mechanism shall come into being for the securing of the continuation of Life, in terms of the biopolitical population (Foucault, 2007, 2010), ought not to be dismissed simply as a Malthusian determinism. In the historical materialist understanding of history, 'There's is a divinity that shapes our ends, Rough-hew them how you will'. I must emphatically state here that no political phenomenon is ever inevitable or irresistible, and I argue that, despite the almost homeostatic quality to its emergence, this is a contingent political reaction to the historical necessity of the 'dangerous' ecological contradictions of capitalism. However, it is difficult to evade the impression that there are profound historical forces at work driving the core states into more comprehensive and profound urban oligarchic structures. The transformations are 'not infinitely contingent' (Moore, 2015, pp. 83, 86), no matter how we attempt to struggle with and counter these emergent oligarchic formations across the globe through new political idioms of the urban form.

It is important to concede that in the ecological metabolism 'nature' can neither be saved nor destroyed, but merely transformed in a matrix with social relations (Moore, 2015, p. 45; Smith, 2007). Ecological crises are therefore chronic, and there shall be no bang, no cataclysm (Streeck, 2016; Zizek, 2010, p. 350), but simply a terraforming of the very parameters of living. With the prospect of a 'forthcoming breakdown of nature', we are reminded that we live in an era where the end of the world is more easily envisaged than the end of capitalism (Zizek, 2012b, p. 1). Thus it is likely that it is the logic of capitalism (accumulation) that will superintend the reconfiguration of these 'parameters' into something that we today might consider the end of the/our world. But how will this be experienced and understood?

Dystopia does not exist, but this is not for the same reason as its more buoyant counterpart. The utopia is 'no place' because it is a horizon of expectation, an imagining of parameters that have as yet no empirical existence. However, the dystopia has no existence by virtue of its very historicity. When tomorrow comes there will be no one left alive for whom it was a dystopia. For those that are born and living in that time, and thinking (hopefully) on the objective world that they encounter each day, the mundane content of our tomorrow (and their today) is their vulgar empirical reality and the best of all possible worlds. Only to the transhistorical and universal observer does the dystopian future have tangible existence. As no such person exists, then neither does the dystopia. Coupled with the almost limitless malleability of an individual's primary socialisation, we must then ask ourselves not whether, but simply how will 'species-man' transition to a future capitalism-in-nature socially disciplined asymmetrically via the contingent geopolitical responses to chronic ecological crises. There is then an 
apparent shift underway in the social metabolism of capital, a metabolism that is 'always geographical', and through which the twenty-first century city facilitates the realisation of a decisive and new 'historical form of humanity-in-nature' (Moore, 2015, pp. 83-84), and one way to approach that form is metropolitan urban oligarchy. ${ }^{2}$ It is to understanding what, how, and why this might be the case, that we must turn our attentions, if we wish to derive more effective political strategies toward emancipatory struggle in the new urban context.

\section{The geotechnic city: global discipline in historical capitalism}

If historical capitalism supposes a tendency toward the enhancement of the productive forces, however historiographically problematic or variable and stuttering in local actuality it might be, then it must also suppose a somewhat proportionate mutation and enhancement in the modulations of discipline and control over 'humanity-in-nature'. This second movement of the materialist symphony - capitalism as a political technology of control over the relations of production - must never be forgotten when considering the forces of production in historical capitalism. Retaining this thought prevents overemphasis on the moment of de-territorialisation in the urban form - with all its productive, creative, and life affirming connotations - at the expense of considering the moment of re-territorialisation necessitated by definition in any axiomatic capitalist reconfiguration, with all its ideologically inconvenient unpleasantness (Deleuze \& Guattari, 2013).

This is not to exclude the contingency of collective or individual human agency from the formation of the urban assemblage, but it opens up new avenues of thought regarding the emergence of the global city in the dynamic terms of a fundamentally ecological reading of historical materialism. It also establishes the urban form in decidedly machinic terms, somewhere between Henri Lefebvre's 'ensembles' and the 'assemblages' of Deleuze and Guattari (Deleuze \& Guattari, 2013; Lefebvre, 1973, 1991, 2009). This is necessary if we want to understand the emergence of the global city as a civilizational 'device' of discipline, critical containment or displacement, and as a mechanism for the transformation of human subjectivities in terms of a new capitalism-in-nature. Urban assemblage thinking allows us to get beyond the preoccupation in Global City research with institutions, individual agents, extensive spatiality, social units, and into imaginative re-conceptualizations that work through the notion of the global city as a 'vortex of habitable circulation' (Virilio, 2006, p. 31). Such a conceptualisation is admittedly quite abstract, but is at the same time 'abstract yet real; ideal yet effective; absolute yet 'differentiated" (Deleuze \& Guattari, 2013, p. 255).

This kind of machinic assemblage-thinking more effectively re-inserts a stronger geographical orientation into historical thinking about global cities and urban agglomerations. This is highly significant for the reason that urban oligarchies are historically predicated on position and positionality, rather than on production, circulation, and migration alone. Identifying these positionalities, in terms conjunctive of the flow of capital through the spatiotemporal intensities of the urban assemblage and the fixities that are necessary for realising value out of that flow of capital, will be essential if we wish to 'trace the workings' of urban oligarchy and its command over the strategic disbursement of capital across the capitalist world-system. 
Along these lines, Lewis Mumford's historical narrative of capitalist technique affords us a useful and pertinent structure for understanding the historical emergence of the Geotechnic temporality in the global city. But it also provides a critical point of departure helpful if we want to grasp contemporary political trends. Developed in the 1930s out of Patrick Geddes' earlier Cities in Evolution (1915), Lewis Mumford carved out three imbricated and overlapping civilizational phases of machinic and technological complex in the social geography of the Western experience: Eotechnic, Paleotechnic, and Neotechnic.

The Eotechnic era (c. 1000-1750) was predicated on the separation of the production of energy from its control and on the 'diminished use of human beings as prime movers' (Mumford, 1955, p. 112). The basic machinic assemblage was formed in the impersonalisation of productive energy and in the appearance of the machine-tool, though with the scale of the machine remaining decidedly human and humane. The vertices, emplacements, and nodes in the mobilisation of matter and energy in the eotechnic phase were the castle, the monastery, the mill, the mounted knight, and latterly the artillery fort and tea clipper. Its principal media were wood, water, and wind, its character is both Mercurial and Dionysian, and its artifices are those of Minerva.

The paleotechnic phase (c. 1700-1900) represents the transition of the machinic assemblage beyond the human scale into that of the industrial organisation of production and a markedly more 'quantitative conception of life' (Mumford, 1955, p. 210). Its tissues, glands, and vascular conduits were the railway, the factory, the steam engine, and the mine. Its principal mode was experimentation and discovery, and its journeymen were the inventor and the heroic capitalist organiser of production. The paleotechnic thrust forth the great industrial expansion of productive power and its corollary, ecologically exhaustive productive frontiers and unsustainable practices of social reproduction in the long-term. It is the world of Prometheus and Hephaestus.

The Neotechnic phase (c. Twentieth Century) emerges as a 'qualification' of the paleotechnic's quantifications (Mumford, 1955, p. 263), and it is characterised by an intensification of the application of a nomological science. From steam engine to internal combustion engine, from factory to laboratory, from mine to vineyard, and from train to motorcar and aeroplane, the neotechnic is a mutation of the earlier phases. Its avatars are the engineer, the scientist, the planning designer, and its trajectory is a quest for ever-greater productivity and efficiency, rather than simple expansion. Crucially, the neotechnic realises technology that disciplines the paleotechnic explosion so destructive of life, and restores the assimilated service of the machine to Man from the paleotechnic subordination of Man to the machine. Symbiosis, synthesis, control, and sustainability would be the watchwords of this phase of machinic civilisation. To Mumford, it is the adult to the eotechnic baby, via the adolescent exuberance of the paleotechnic (1955, p. 212). It is Apollonian by its rule of Reason.

The great problem with Mumford's Neotechnic era is its inescapable utopian quality, its lack of historical contingency, its over-optimistic departure from industrial pathologies, its schematic naivety, and its absent account of unexpected morphologies. To him, our twentieth century failure to depart from 'bellicose, money-centred, life-curbing' paleotechnic practices represents a 'miscarriage of the machine' and a missed opportunity for civilizational transcendence (Mumford, 1955, p. 264). In his desperation to restore the bucolic into the industrial, he posited a great technological-civilizational maturation and failed to anticipate the asymmetric and perpetually shifting ontology of global capitalism that is 
driven by the logic of accumulation crises. The result was to treat the Neotechnic as a blanket civilizational end-zone to Modernity, rather than a historical idiom in which remarkable spatio-temporal displacement, theatrical destruction, and local exhaustion could and would still take place as necessary to that logic. In this spirit, what might be more salient to identify is the technology of social and political control realised in each of these eras through the transforming matrix of the machine sensu latissimo. It is to map out the modality by which humanity, individually and in association, has been disciplined, policed, dominated, governed, mobilised, and ordered through different machinic and technical assemblages, which always nevertheless entail an essential geographic dimension. Specifically, it is to the particular role of the city, or 'urban assemblage', that we must look to illuminate the transformation in civilizational technics in our time of rapid urbanisation across the face of the Earth. This is what is meant by Geotechnics.

The Geotechnic can be provisionally understood as a historically idiomatic aspect of the Neotechnic. Broadly, it is a way of understanding the emergence of those 'particular historical-geographical formations' that bundle 'human and extra-human natures' together in the oikeios topos of a capitalism that is dialectically webbed with 'nature' (not Nature) no longer treated as an object (Moore, 2015, pp. 35, 38). More precisely, within the Neotechnic, the Geotechnic idiom appears from our historical situatedness in media res as a 'mesotechnic' period of transformation and transition in human association through reconfigurations of 'historical nature' (Moore, 2015, p. 12; Mumford, 1955, p. 165), and which is characterised strategically by a particularity of historical-geographic form: the geotechnic assemblage.

One might object that the idiomatic particularity of the Geotechnic cannot really be distinguished from the more general Neotechnic. However, I argue that there is a crucial line of differentiation. For Mumford, the Neotechnic constitutes a realisation of the potential for a superior technical organisation of human life made possible by the transitional and revolutionary unleashing of forces and technique in the paleotechnic phase. There is a sanguine horizon of expectation in the neotechnic trajectory, and a dialectical motor of transcendence. However, the Geotechnic offers a more pessimistic (or nuanced) expectation of spatio-temporal containment and displacement of the potentiality released by paleotechnic transitions, at least in what Mumford himself alluded to in passing as a 'meso-technic' period of transition (1955, p. 165). Lets assume that 'machines are easily matched with each type of society' for the reason that 'they express those social forms capable of generating and using them' (Deleuze, 1992, p. 6), and that similarly 'the machine cannot be divorced from its larger social pattern; for it is this pattern that gives it meaning and purpose' (Mumford, 1955, p. 110). In accord with this, a geotechnic (meso-)phase of machinic assemblage can be differentiated from other phases by the 'historic mission' of its function in a wider matrix of social, material, and even ecological, relations. In short, whilst the Neotechnic offers the fruits of a more rational organisation of the paleotechnic explosion, the Geotechnic represents a tighter disciplining of global populations within that rationalisation due to those ecological contradictions that Mumford failed to anticipate in his rosy teleological vision of neotechnic possibilities, and enforces politically how those fruits are to be shared by humanity-in-nature. The 'historic function' is what differentiates the Geotechnic within the Neotechnic as one of 'the waves of geographical restructuring' in the dominant regime of capital accumulation (Moore, 2015, p. 95). 
The aim here is not to slip into the somewhat naïve narrativisations of Geddes and Mumford. Of course, cities have always been implicated in the discipline, surveillance, and control of populations, right back to antiquity, but the question now is one of quality, kind, extent, and particular historic function.

It has happened already. In the wake of the Great Depression and the Second World War, cities emerged from their paleotechnic adolescence into a first phase geotechnic reconfiguration of their form, in order to meet the exigencies of their greater 'historic function' in integrated world capitalism at that time: the resolution and displacement of spatiotemporal crises in capital accumulation. In this so-called 'Phase One', we are speaking of the post-war suburbanisation, expansive consumption-capitalism, and the Cold War, which evaded the crisis of the paleotechnic but never genuinely departed from its destructive tempos and logic. However, the suburban solution to the spatio-temporal contradictions of capital accumulation, that was 'building tract houses and filling them with things' (Appelbaum, 2011; Harvey, 2013, pp. 50, 130-131), is over. The compensation to the working class, for their subordination and relative exploitation, with consumerism will most likely reach the 'ecological limits to capitalist growth' in the twenty-first Century as the BRIC continue to industrialise (Panitch \& Gindin, 2011, p. 16), as the global population continues to increase, as capitalist penetration of lifewords intensifies, and as the 'frontier' to capital is internalised to the core states. The contradictory dynamic in a Phase One defined by the automobile, the suburban home, consumer capitalism, and Fordist production regimes, has reached the point of either critical sublation or displacement, and new disciplinary 'grand ensembles' of spatio-temporal fix seem on the cusp of realisation (Lefebvre, 2009, p. 184fn17). But rather than spreading the power to command labour and marshal material resources, this Phase Two will severely restrict it to the oligarchic positionalities.

The dismissal in the 1980s of the argument that cities would invert in the 1990s-2000s due to impending energy crises (Sharpe \& Wallock, 1987, p. 33), returning wealth and concentrating capital to the centres once again, has proven to be rather hasty. Perhaps the scepticism of this prospective development, which has now come to pass, stems from a concentration on production and de-territorialisation over a more pertinent consideration of the re-territorialisation of consumption and techniques of appropriation. Whilst production processes admittedly continue to evade urban recentralisation, it is in the apparatuses of consumption and the appropriation of value from the global flows of capital that one can see the return of capital concentration to the urban centres of the Global City, or at least control of capital. What we see now, in the geotechnic assemblage, is the continuation of the urban form as the principal locus of geostrategic command and resolution for spatio-temporal crises in global accumulation, but as a historical and geographical inversion of those Phase One geotechnic axioms into a Phase Two of austerity, enforced scarcity, and a new post-disciplinary subjectivity inscribed by apparatuses of capitalist governmentality, where the restriction or re-articulation of consumption and the occupation of space is the key. Perhaps it is in the transitional aporia between these two orientations that our political struggle will crystallise?

I would justify the term Geotechnic to designate the transformative complex in question, rather than the equally plausible alternatives of oikeiotechnic, proteotechnic, urbotechnic, or architechnic, for a number of reasons. Firstly, because there is a distinctly geographic quality to the emergent technological complex of control as realised in global cities and 
their urban spatio-temporalities. Whilst there is an undoubted geographical aspect to all phases of machinic and technical development, geographical technique is absolutely central to the geotechnic complex especially and is so in ways particularly germane to matters of geography, territory, and space. Secondly, the term refers to the entire Earth $(\gamma \eta)$. The disciplinary logic of the geotechnic is not localised to a single particular spatiotemporal theatre of capital accumulation, but is truly global in reach, as it must be in order to affect planetary ecology. The Global City as a geotechnic assemblage offers then a strategic formation for the 'coordinate development of a higher social purpose' (Mumford, 1955, p. 266), in this case the higher global purpose of planetary ecology in dialectical relation to human habitation. Therefore, as a geotechnic, it is at the scale of the urban that 'an abstract global reach attains everyday coherence' (Merrifield, 2006, p. 88). The urban form offers the most promising geographic and historical particularity for the realisation of this disciplinary synthesis. The implication is that, in the historical context of advanced or axiomatic capitalism, we must now reckon with 'the essential planetary basis of technology itself' (Mumford, 1955, p. 142), for which the disciplinary institutions and 'armatures' of paleotechnic transformation (ie. Factory, Hospital, Prison, Barracks, School) have become utterly inadequate (Deleuze, 1992; Foucault, 1991, p. 305). The city assemblage effects global social forces, and so its civilizational technique is decidedly geo-technical.

It is crucial to stress that the geotechnic is not necessarily a periodisation, but likely a more or less drawn out moment of re-configurative transition (meso-phase). Just as Geddes saw his fin-de-siècle Present as a transition from the paleotechnic to neotechnic city, maybe the geotechnic assemblage is a transitional phase of relatively short lifespan. But then, maybe not. It would be wise neither to speculate a grand Malthusian limitation on future ecological limits nor to indulge in the blithe pseudo-Schumpeterian assumption of an expanding possibility frontier. The point is to recognise the geo-strategic parameters of what is both actual and potential in the apparent logic of the transformations that characterise the topological immediacy of our urban experiences, in order to perceive in them a new idiom of capitalist command and control.

This is not just another geo-determinist piece of longue durée history, as we have already been supplied generously in the works of Diamond (2005), Kaplan (2012), Herbst (2014), or even, arguably, Landes (1999). Nor is it properly a geo-social history of the kind familiar from the Annales historians like Braudel (2002a, 2002b, 2002c) or Febvre (2009). It is rather a matter of the spatio-historical articulations and reconfigurations of the capitalist world-system and its historic civilisation set into the terms of worldecology. If there is an ontological framework here, it is that of the dynamic molar and molecular territorialities found in the 'new materialisms' of critical social science.

It might be asked at this point, how can the Marxian and poststructuralist traditions of critical materialism be reconciled in this conceptualisation of the city-assemblage as a response to ecological crisis? The tensions between the respective philosophies of Transcendence and Immanence, upon which these two strands of the 'new materialism' discourses are situated, often seem something of a false opposition. 'Totality' and 'substance', 'particular' and 'attribute', 'dialectic' and 'multiplicity' often seem to be diverse ways of speaking about the same thing through different onto-epistemological idioms - respectively Hegelian and Spinozist. Marx's political economy, and the critical human geography inspired from it, can be understood through either and both. 
Scholarship on the 'urban assemblage' has coalesced principally from two fundamental directions. The first direction would be the Marxist critical geography of Henri Lefebvre (1973, 1991, 2009), for whom the 'ensemble' constituted a key spatio-temporal point of articulation in the movement and reproduction of capital and a device for the realisation of crises in capital accumulation. The second direction would be the 'machinic assemblage' of Gilles Deleuze and Felix Guattari's A Thousand Plateaus (2013), which draws on the rather obscure philosophical traditions of Immanence (Spinoza, Bergson), and which expresses much through botanical, anatomical, physiological, and geometrical metaphor. Bringing these two traditions of critical analysis together - Lefebvre's 'ensembles' and Deleuze/Guattari's 'assemblages' - a synthetic analysis can be worked through whereby the city-assemblage it treated at once as an architecture and a medium so as to bring out both fixity and flow.

The utility of the Deleuzo-Guattarian strand of assemblage thinking flowing from this has been brought out in the journal City, where Colin MacFarlane and others have attempted to translate it into the molecular terms of radical urban movements. Here the promise lies in more effectively critiquing 'bourgeois forms of knowledge' about the urban (Brenner, Madden, \& Wachsmuth, 2011; McFarlane, 2011a, 2011b, 2011c; Watt, 2016). By alloying this vector of analysis to Lefebvre and David Harvey's Marxist 'ensemble', a line of critical analysis can be opened that allows a sensitive consideration of the material social metabolism where so much Deleuzo-Guattarian thinking has been allowed to spin off into the virtual ether.

The problem arises when we ask how Marxist (Hegelian) notions of contradiction and crisis, with its transcendental assumptions of alienation and ontological separation, can be situated into this 'plane of immanence'. There is no time here for a treatment of this knottiest of philosophical problems in so-called Continental Philosophy. However, to those who assume that to speak in Spinozist, Foucauldian, and Marxist terms simultaneously is to make a faux pas, I would draw their attention to Frédéric Lordon's Willing Slaves of Capital: Spinoza \& Marx on Desire (2014), in which he deftly combines Marx's 'structuralism of relations' with Spinoza's 'anthropology of passions' into a synthetic presentation of 'regimes of mobilization' (2014, pp. x-xi). This is what the city-assemblage is become, and in the ecological totality/substance we can provisionally take 'contradiction' as something neither necessarily binary nor teleologically transcendental, but a way of placing in relation to one another a multiplicity of social forces within an ecological totality/ substance.

\section{Authoritarian governmentality: controlling the social metabolism}

Stephen Graham's book Cities Under Siege (2010) thoroughly explores the trends toward securitisation and militarisation of social life through the increasingly dominant urban form. My aim here is to continue this track of critical analysis, but along the lines introduced at the outset: political technology and topology. In terms of the former, Graham's militarisation of the urban space blurs quite considerably with the rationality of police. As police forces are militarised, so military operations more closely resemble police actions. It is by exploring how the global city as an urban assemblage facilitates the broader 'police science' of authoritarian governmentality brought to crisis by the forces of ecological contradiction in the world-system that the logic of this militarisation can 
be brought out of the innumerable anecdotal trends. Regarding the latter, by treating the global city assemblage in more topological terms, the longer term historical forces of crisis can be addressed in a manner that illuminates the emergence of metropolitan urban oligarchy as a generalised contingent political response to crisis. In short, the aim is to provide a historical Reason to the trends adumbrated in Graham's work.

Similar to 'authoritarian neoliberalism' (Bruff, 2014), the term 'authoritarian governmentality' has been recently introduced by Lazzarato (2015, p. 169), and offers a particular nuance on the theme of 'capitalist governmentality' (Welsh, 2016). As the 'disciplinary sites of enclosure' undergo crisis in a 'process of substitution' (Deleuze, 1992, p. 7), and are 'dovetailed' into more effective means of population control, organisation, and mobilisation through apparatuses of governmentality (Foucault, 2003, p. 242), we must come to identify the strategic means by which this grand reconfiguration might become realised on the level of the capitalist world-system. In a twenty-first 'century of the city', it is to the strategic dispositif (apparatus) in the context of that world-system that we should look. The 'geotechnic city' is just such an apparatus.

Governmentality is a portmanteau of 'Government Rationality', and as a rationality it refers to a 'specific form of normative political reason organizing the political sphere' in the history of Modernity (Brown, 2006, p. 693). Within the terms of this rationality, it is also a mode of government constituted 'by institutions, procedures, analyses and reflections, calculations, and tactics' into an ensemble (Foucault, 2007, p. 108). Through this ensemble, power is not 'exercised' by discrete and delimited subject-agents, but takes the more plural and singular form of 'actions upon other actions' (Foucault, 2002b, p. 341). Its principal mechanism therefore is the apparatus (dispositif), which is enunciated by pastoral or 'governmental' practices and techniques. The object of this governmental power is not the individual, which is subordinated to an instrumental role as expendable 'collective individual', but the continuity and biopolitical wellbeing of a given 'population' (Foucault, 2007, p. 21).

Governmentality is placed in a genealogy of modern modalities of power beside Sovereignty and Disciplinarity. Whilst being situated respectively in a loose periodisation of sovereign, disciplinary, and governmental modalities of power, this genealogical movement is not characterised by temporal succession or supersession (Foucault, 2007, p. 8). Foucault characterised their mutual relationship as that of 'dovetailing', that is, imbricated and accretional, rather than teleological or discretely periodised. ${ }^{3}$

Sovereign power is then that power 'exercised' by a sovereign-agent on the subjects inhabiting a juridico-political territory. It is the power of the medieval monarch or lord, who directly exercises sovereignty over the bodies of those over whom it rules, and possesses the power to 'let live, or make die'. It is a personal anatomical power. The non-homologous resistance it engenders by the surplus application of its modality of power is 'rebellion', and its insufficiency lies in its vulnerability to rebellion and in its ineffectiveness in transforming individuals.

Emergent in the early-modern era, and most fully expressed in the transformations of the paleotechnic, disciplinary power is a social anatomical power predicated on enclosure and the principle of panoptic surveillance that functions through semio-techniques of representation and micro-physical somatic disposition (Foucault, 1991, 2006). Its object is the 'soul' through techniques primarily aimed at the body, in order to effect pedagogic transformation of an individual's subjectivity, and takes the form of a 'formation of habits' 
(Rancière, 2012, p. 31). Its institutional settings are the prison, school, hospital, barracks, and factory. The non-homologous resistance it engenders by the surplus of its applications is 'escape', and its insufficiency as a political technology in historical capitalism lies in its inadequate productivity, its inadequate power to mobilise and canalise conative investments, and the inadequate totality of its control over the individual.

The mode of governmental power emerged historically in the eighteenth century crisis of mercantilism, and took the form of 'political economy' and 'police science' (Polizeiwissenschaft), by which states could make interventions into the populations over which they were to govern according to pastoral principles (Foucault, 2007, pp. 106-108). This is the 'age of security', where 'Man-as-Species' becomes the regulated object (Foucault, 2003, p. 242). It is a social physiological power, and thus it has no institutional setting. Its topological metonym is the 'labour camp' (Welsh, 2016), and its instantiations are non-subjective, not enclosed, and operate through the vertex of emplacement and flow. Its strength lies in the seeming absence of surplus to the actions upon actions that constitute its operation. As such, its superior 'mobilisation of energy' (Rancière, 2012, p. 31), and the canalisation of conative investments by which it coerces (Lordon, 2014), obviates non-homologous resistances in a totalising 'society of control' (Deleuze, 1992). The basis for a political ecology in the twenty-first century is derived from the notion of the governmentality of a given biopolitical population. Governmentality as relates to the regulation of a population is 'environmental', and generative of a milieu that shapes the automaticity of responses to systemic change. As such it is physiological and systemic. The geotechnic city, conceived as a grand strategic apparatus of reconfiguration in the governmental regime of capital accumulation, constitutes a 'technological complex of possibilities' that facilitates the 'active realisation of opportunities for direct capital accumulation' (Harvey, 1996, p. 46).

In terms of social control, we are shifting from disciplinary 'molds', whose institutional armatures are already in crisis, to those governmental 'modulations' that are controls that act 'like a self-deforming cast that will continuously change from one moment to the other, or like a sieve whose mesh will transmute from point to point' (Deleuze, 1992, p. 4). We must then ask ourselves what formations, structures, and apparatuses will emerge to operationalise the modulations of this rationality. Recent governmentality literature has renovated the notion of territory and territoriality. This foregrounds the necessarily geographical character of the 'apparatuses of security' (dispositives) that are the principal mechanisms of modulation in the police science of governmental power (Agnew, 1994, 2005, 2013; Anderson, 1996; Brenner, 1999; Elden, 2013a, 2013b), in addition to statistics, indices, and epistemes. This is the 'police power' of the global city in the changing axiomatic of capitalism in chronic ecological crisis.

'Police' signified a program of government rationality ... a project to create a system of regulation of the general conduct of individuals whereby everything would be controlled to the point of self-sustenance, without the need for intervention. (Foucault, 2002c, p. 351)

In this way, we can see how it is through the city that a territorialised apparatus of governmental power in the capitalist world-system can inscribe a disciplinary control of biopolitical populations across territorialised space without the device of institutions superannuated in the age of security. This is the global city form as an apparatus where 'at the center the decisive knot of the capital where the right triumphs, and all around 
the vast camp of the suburbs and provinces' (Virilio, 2006, p. 40), and through which the ecological contradictions of capital accumulation are resolved by combining the government of populations with the disciplinary transformation of individuals' subjectivities.

We can see in the examples below how the particular effectiveness of the city-assemblage in controlling populations can be summarised by reference to its closing spatial syntax. This concept brings into mutual relation the spatio-temporality of the various techniques in the apparatuses of authoritarian governmentality in a manner more propitious than in other geo-social formations. This closing syntax entails both the discrete lines and coherences implied in a social architecture of fixity, and the spatial intensities envisaged when one speaks of a fluvial medium. The spatial syntax of the city-assemblage, which is necessarily closing given the historical ecology of contradictions and its disciplinary imperatives outlined above, combines thus the city as both architectural 'site' and 'medium that is forever contingent and in flux' (Weizman, 2006, p. 53). This closing syntax between fixity and flow facilitates the operation of techniques of control that bypass the 'security' problem of individuals being 'effectively indistinguishable from the wider population' (Graham, 2010, p. xii), a pre-requite for governmental intervention into the biopolitical population. In panoptic terms of surveillance and policing, the global city-assemblage more easily renders individuals into 'cooperative targets' for security and regulatory intervention and socio-physiological regulation (Graham, 2010, p. xii), and into pliant subjectivities regarding the patterned and conditioned response to changing economic circumstances.

The imprint of these apparatuses of authoritarian governmentality, driven by the historical social force of ecological contradictions, can be identified in a number of exemplary areas of civic transformation and social policy. Taking the particular case of London, it ought to be apparent that precisely the kind of profound changes I have mentioned in internal structure, in socio-physiological schematic, and in global position have been effected there over the last three decades, and that social forces driven by global ecological contradictions have informed these reconfigurations through the formation of immanent contradictions.

Housing: with the demand for real estate acquisition in London increasing over decades, the national government's Housing and Planning Act 2016 represents the maturation of a three decades long trend. It demonstrates a clear will to rid London of its remaining stock of social housing, which currently stands at about $1 / 5$ of the total housing stock across the city (Mayor of London, 2015, p. 12), and which is topographically arranged into about 3500 housing estates of about 360,000 homes (Elmer \& Dening, 2016, p. 273). Politically reclassified as 'brownfield' sites ripe to be handed over to the developers (Glucksberg, 2016, pp. 238-239), so as to realise their awesome exchange-values, their inhabitants are to be deprived of their use-values and resettled outside of the central regions of the city to make way for human beings more socially desirable to the bourgeois progenitors of the new cityscape. We are effectively witnessing a 'social cleansing' of the inner regions (Elmer \& Dening, 2016, p. 276; Watt \& Minton, 2016, pp. 211-212), as the city is terraformed into a new social anatomy, characterised by soaring land value, concentration of executive decision-making, population expulsion, restricted spatial access to necessities and consumables, and the ideological and cultural buttressing of massive wealth asymmetries. Demographic and migration pressures have created a contradiction 
between use/exchange values results in a housing crisis, and this is the contingent political response: metropolitan oligarchy formation.

Work and Consumption: There is a sense that, in addition to the traditional poor and indigent who are to be 'cleansed', it is now the Middle Class who are to be eliminated from the Zentrum as it morphs into an enclosed and gated refuge for the oligarchic Last Man of a contradiction-ridden consumer capitalism in ecological crisis. As a 'luxury capitalism can no longer afford' in its new global ecology (Zizek, 2008, p. 29), the middle class consumer must be transformed into the domestic servant, personal retainer, or security auxiliary in the emergent oligarchy of the geotechnic assemblage, or otherwise be consigned to a cellular provincial existence of labouring far from the principal zones of consumption, leisure, and the privileges of socio-aesthetic enjoyment. It is as though what Horkheimer presaged in The Authoritarian State is becoming actual, a situation where 'the [non-rentier] bourgeoisie has been decimated, and the majority of the middle class have lost their independence; where they have not been thrown into the ranks of the proletariat, or more commonly into the mass of the unemployed, they have become dependents of the big concerns or the state' (Horkheimer, 1985, p. 95). Contradiction between the imperative for compound growth (accumulation) and the ecological limits to growth result in a contingent political response in the form of consumption restriction (and in the means to acquire such access - salaried work).

Transport: Strategic initiatives like HS1/HS2 and Crossrail promise to recast the social physiology of the city in the brachial terms of the reproduction of capital and the arborescent operations of its power connections, rather than on the terms of the dispersed human material that it intermittently requires for its valorisation. As Haussmann built 'the efficient circulation grids of Paris, which catered basically to the financial interest of the upperbourgeois supporters of Napoleon III' (Lowe, 1982, p. 68), Joseph Paxton likewise proposed a similar Great Victorian Way (1855) for the east-west traffic flow of London that was never realised ... until Crossrail. The enhanced motility of capitalist fractions is matched in these strategic transport developments by the corresponding immobilisation of geographic and demographic elements that inhibit or problematise the sovereign logic of capital and its consequent spatial dispositions. The emphatic and contrived connectivity of the spectacle-establishing Stratford Olympic Park to the city's arterial transport nodes and the Westfield consumption arena is matched only by its equally contrived hermetic sealing off from the surrounding estates of social housing and undesirable surplus humanity. These kinds of juxtaposition in relative mobilisation and inertia across the changing social geography of the city are stark and increasingly open to systemic mapping of the most political kind. Contradiction emerges between the annihilation of space through time in transport advances and the ecological limits of mass population motility and energy consumption. Restriction of transportation to a oligarchic minority emerges as a political response.

Leisure: The connection between Housing, Work, Transport and Entertainment is tight. The ligature especially between spectacle and the ploughing of surplus capital into grand infrastructural projects centred on consumption is now axiomatic (Debord, 2014; Harvey, 2010a, pp. 85-86, 174-175). The symptomatic case of the London Games 2012 is merely the apotheosis of a whole host of spectacular developments that have placed 
the needs of capital accumulation before the needs of human inhabitants. ${ }^{4}$ Such projects are always profoundly geographical as they entail the transformation of land use for the leisure pursuits of a decreasingly small number of the privileged to the exclusion of the many, to whom access and enjoyment must be either denied or severely restricted and regulated through the police mechanisms of price, TV, and the privatisation of space. It is Norton Long's walled city built for the 'favoured few' (Long, 1972, p. 4). Contradiction is entailed in the need to realise capital without distributing spending power (and all its politically subversive implications). Spectacle as a police apparatus is the contingent political response.

Policing: More intimate direct Policing has been an obvious feature of life in the city for decades now. The police power operates through the concentration of population and their spatial dispositioning, and therefore goes hand in hand with increased surveillance (Minton, 2012, pp. 32, 46-47). ${ }^{5}$ Terrorism Acts, and an increasingly armed police force (Nickerson, 2016; Wilkinson, 2016), equip the institutional police with a purpose more germane to the protection of property and the smooth running of the city on the terms of capital. There is a strong sense that policing is motivated not by a guaranteeing of the mutual independence and autonomy of democratic citizens on a zero-level of equality in the public sphere, but by a security reaction that backs up the emergent oligarchy in face of the pressing contradictions of political ecology that I am identifying here (Brown, 2006, p. 704).

The territorialised operation of power in the governmentality concept helps us to understand how the emergent political technology of control is connected to the social metabolism of capitalist reproduction in terms of global ecology. Through the device of the global city, the police power in governmentality is 'precisely a technique of assemblage, whose principle task is to articulate, on behalf of the market, the relationship between the economic, the political, and the social' (Lazzarato, 2015, p. 128), which will take us to the social metabolism and the materiality of its dynamic operations. As the social metabolism is 'a flow of flows in which life and matter enter into specific historical geographical arrangements' (Moore, 2015, p. 84), so it is in the concept of the assemblage that the new 'arrangements' - the political technology of governmental apparatuses - can be given more explicitly geographical and ecological logic. It is in this way that Graham's war being waged by metropolitan oligarchies on their own populations via militarisation of police through the urban medium can be understood as a contingent response to deeper social forces beyond the simple will to dominate and control.

Through the lens of governmentality, territory and territorialisation offer to take us beyond the 'spatial' way of understanding the urban form that has been so helpful in perceiving and critiquing the enclosures of disciplinary power, but which is now inadequate. The aim is to understand these new modulations of control over the social metabolism of the capitalist world-system (conative investment, affect canalisation, limitless postponement, hyper-panopticism, amongst other meta-disciplinary techniques), the possibilities of all of which are enhanced by the urban-assemblage more than any by any other geo-social formation. This opens up a window onto how the geotechnic city will function as an emergent strategic device of control and transformation in the global political ecology of the century ahead, and how this must principally be realised through the oligarchic structure (Rancière, 2014). In the materialist understanding of historical capitalism, 
techniques of power are invented to meet the demands of production and the imperative of continuing capital accumulation, including the 'production of destruction' should this be necessary in terms of ecological totality (Foucault, 1980, p. 161).

If compound growth of the capitalist totality cannot be continued at the level of the totality, this growth will have to become a strictly localised phenomenon, with acute asymmetries in capital accumulation enforced, entailing austere zero-sum regions of no-growth or even local regression. Politically, this means that this governmentality will have to be increasingly authoritarian, that is, indifferent to individual human lives, if resolution and displacement of ecological crises are to be possible within the medium of capitalist social relations. It has been noted already that the institutions and political culture of liberal democracy seem to be 'passing into history' leaving us with a 'historical supersession of liberal democracy' (Brown, 2006, p. 691), and that there are deep structural, even geostrategic, social reasons for this. The literature on governmentality will be essential for grasping how a kind of authoritarian pastorate is emerging as 'ultrarapid forms of freefloating control' replace 'the old disciplines operating in the time frame of a closed system' (Brown, 2006, p. 706; Deleuze, 1992, p. 4), but in a way that marks expendable 'collective individuals' in the population that are 'simply instrumental' for the continuation of the biopolitical population of the capitalist totality, operative in terms of the continued accumulation of capital in critical contradiction (Foucault, 2007, p. 42).

My aim is to contextualise experiences against this strategic backdrop and to destabilise any smooth acquiescence to all those very reasonable demands made by authority at the tactical level as it terraforms our urban topographies. For when set into the longue durée of historical capitalism, and into the geostrategic apparatuses of the capitalist world-system that arise to manage its strategic ecological contradictions, these 'reasonable' demands for the greater good, such as 'Austerity' or long-term enforced scarcity, transform before our eyes into elements of a rationality of authoritarian government of the few, by the few, for the few, as capital accumulation sputters and starts. The general terms for battle are thus established, and the global city is the field upon which this battle will be played out.

\section{Conclusion}

The first purpose of this article has been to provide a historical reason for the apparent trends characteristic in the emergence of global cities over recent decades - global ecological contradictions in the capitalist-world-system. The second aim has been to begin new lines of analysis beyond the extant Global Cities literature, to identify the form and logic of the authoritarian governmentality crystallising around these contradictions out of the political activities of power elites. This is the critical agenda I propose.

Bringing together Marxian, Foucauldian, and Deleuzo-Guattarian thought - respectively, global political economic crisis, governmental apparatuses, and assemblage-thinking - as three vectors of critical analysis that mutually inform one another, is possible if we embrace a pragmatics by which 'knowledge should no longer be judged on the basis of its isomorphic relationship to the external realm, but on the basis of what kind of contribution it makes to our world' (Baert and Carreira da Silva, 2010, p. 296). This is intellectual praxis, and by colliding these traditions can we produce 'revolutionary fire' (Harvey, 2010b, p. 4). 
The thrust of my analysis is to advocate for a more critical and politically conscious agenda in academic discourses regarding the Global City formation in particular. I want us to return to the more critical spirit of Friedmann and Wolff's earlier formulation of the World City, whose critical edge has been diluted by the subsequent Global City research orientation. As such, I share the same stated aims that Friedmann and Wolff did 35 years ago: a 'heuristic purpose', an 'enlightening purpose', and a 'predicative purpose' (Friedmann \& Wolff, 1982, p. 310). Regarding the first, I want to account for what we are witnessing through the transformations of our global cities. Regarding the the second, I want to illuminate what the Global Cities research agenda leaves in the dark. Finally, I want to set the groundwork for a new problematic out of which a different idiom of political action might be conceived in the urban struggles ahead.

To summarise, the emergent zero-sum accumulation regime, and the materialisation in response of authoritarian technique through global cities characterised by their closing syntax of control, engenders apparatuses more reminiscent of feudal social relations of dispossession and appropriation than purely capitalistic ones of exploitation through expanded reproduction. For a 'low-energy cosmopolitanism' (Graham, 2010, p. 382; Dobson and Hayes, 2008) to replace the contemporary trajectory toward metropolitan oligarchy as the dominant contingent response to ecological crisis through global cities, I argue that an assault on the privileged positionalities of surplus extraction in the global city will be imperative.

The appropriate intellectual response would then be to focus critical analysis on a number of political geographic features in the formation of Global Cities, in order to formulate effective 'countergeographies' to the oligarchic power (Graham, 2010, pp. 348385), themes that are mostly absent from the Global Cities research literature. Based on the above, I suggest that these would revolve around a number of especially important manoeuvres: (1) challenge the celebratory Liberal view of the Global City as a site of wealth creation, production, and irenic reproduction; (2) reinsert a more serious analytical consideration of the geographic and material into an increasingly virtual, ethereal, and abstract discourse; (3) to this end, identify the emergent architecture of 'positionalities' in the global city, and its reproduction through contingent political action; (4) resituate this urban architecture into the dominant global regime of capital accumulation in the longue durée of the world-system in terms of ecological contradictions in that system; and (5) re-articulate the concept of Class in this structure, class understood not in the terms of the industrial nation-state, but in terms of the social relations generated in particular spatio-temporal settings by post-industrial urban assemblages (i.e. 'city-state' Britain).

In the British case, it is to the spatio-temporal particularity of, what might be termed, the axiomatic city-state that I want to turn this historically broader and spatially general analysis. This spatio-temporally particular structure in the political geography of advanced capitalism is especially pertinent to the contemporary politics of the British state-territory. The broader analysis in this article provides the necessary setting for the more contextual analysis, in order for us to understand this particularity in the world-system and contrive the necessary conceptualizations for further critical analysis, as well as political praxis.

The political implications of this analysis are that we must consider how we want to situate our political agency between the perennial contingency of political action and the historical social forces that limit any such action. Most importantly, it is to the 
neglected question of how these forces of transformation are experienced, and then intellectually made sense of, that is acutely important for present and future strategy.

\section{Notes}

1. In the British context, one can see how the rise of UKIP and the movement toward EU-Exit in the provinces, set against the backdrop of strategic deindustrialisation and 'National Austerity', are symptoms of this reconfiguration in the relations of political and social power in that polity.

2. Oligarchy is to be understood as a class, and the form of political form of social organisation it entails, not as the cabal of individuals that has become the popular understanding of the term since the collapse of the Soviet Union.

3. The subtle temporality of this non-aetiological and non-teleological presentation is mirrored in Mumford's civilizational technics, as well as in Donald Lowe's historic 'perceptual fields' that 'do not simply displace one another', but rather where 'one is superimposed over the old' (1982, p. 14). The similarly accretional or sedimentary relating of Eotechnic, Paleotechnic, and Neotechnic phases, in the former, and the Medieval, Renaissance, Estate, Bourgeois, and Contemporary fields, in the latter.

4. Aside from the Olympic Games, there stand the Shard, The Gherkin, The Cheesegrater, and Heron Tower.

5. Britain in particular is now notorious for being one of the most surveilled societies in the world.

\section{Acknowledgements}

None, other than to the reviewers, who executed their function splendidly.

\section{Disclosure statement}

No potential conflict of interest was reported by the authors.

\section{Notes on contributor}

John Welsh is a researcher at the Social Science Faculty, University of Helsinki. His current work is on Global Cities research as well as on the transformations of academia in historical capitalism. Recent publications have appeared in Critical Sociology, Housing, Theory, and Society, as well as the International Journal of Politics, Culture, and Society.

\section{ORCID}

John Welsh (D) http://orcid.org/0000-0002-7136-1001

\section{References}

Agnew, J. (1994). The territorial trap: The geographical assumptions of international relations theory. Review of International Political Economy, 1(1), 53-80.

Agnew, J. (2005). Sovereignty regimes: Territoriality and state authority in contemporary world politics. Annals of the Association of American Geographers, 95(2), 437-461.

Agnew, J. (2013). Territory, politics, governance. Territory, Politics, Governance, 1(1), 1-4.

Anderson, J. (1996). The shifting stage of politics: New medieval and postmodern territorialities?. Environment and Planning D: Society and Space, 14(2), 133-153.

Anderson, P. (1978). Passages from antiquity to feudalism. New York: Verso Books. 
Appelbaum, B. (2011, July 28). A recovery that repeats its painful precedents. New York Times Business Section.

Aronowitz, S. (1981). The crisis in historical materialism: Class, politics and culture in marxist theory. South Hadley, MA: J.F. Bergin Publishers.

Baert, P., \& Carreira da Silva, F. (2010). Social theory in the twentieth century and beyond. Cambridge: Polity.

Braudel, F. (2002a). Civilisation and capitalism, Vol. 1: The structures of everyday life. London: Weidenfeld \& Nicolson.

Braudel, F. (2002b). Civilisation and capitalism, Vol. 2: The wheels of commerce. London: Weidenfeld \& Nicolson.

Braudel, F. (2002c). Civilisation and capitalism, Vol. 3: The perspectives of the world. London: Weidenfeld \& Nicolson.

Brenner, N. (1999). Beyond state-centrism? Space, territoriality, and geographical scale in globalization studies. Theory and Society, 28(1), 39-78.

Brenner, N., Madden, D., \& Wachsmuth, D. (2011). Assemblage urbanism and the challenges of critical urban theory. City, 15(2), 225-240.

Brown, W. (2006). American nightmare: Neoliberalism, neoconservatism, and de-democratization. Political Theory, 34(6), 690-714.

Bruff, I. (2014). The rise of authoritarian neoliberalism. Rethinking Marxism, 26(1), 113-129.

Debord, G. (2014). The society of the spectacle. London: Rebel Press.

Deleuze, G. (1992). Postscript on the societies of control. October, 59, 3-7.

Deleuze, G., \& Guattari, F. (2013). A thousand plateaus. London: Bloomsbury.

Diamond, J. (2005). Guns, germs, and steel: A short history of everybody for the last 13,000 years. London: Vintage.

Dobson, A., \& Hayes, D. (2008, October 22). A politics of crisis: Low-energy cosmopolitanism. OpenDemocracy.net

Elden, S. (2013a). The birth of territory. Chicago: Chicago University Press.

Elden, S. (2013b). How should we do the history of territory? Territory, Politics, Governance, 1(1), $5-20$.

Elmer, S., \& Dening, G. (2016). The London clearances. City, 20(2), 271-277.

Febvre, J. (2009). A geographical introduction to history. London: Routledge.

Foucault, M. (1980). Power/knowledge: Selected interviews and other writings, 1972-1977. New York: Pantheon Books.

Foucault, M. (1991). Discipline \& punish. London: Penguin.

Foucault, M. (2002a). 'Omnes et singulatim': Towards a critique of political reason. In J. Faubion (Eds.), Essential works of Foucault, 1954-1984, volume 3: Power (pp. 298-325). London: Penguin.

Foucault, M. (2002b). The subject and power. In J. Faubion (Eds.), Essential works of Foucault, 19541984, volume 3: Power (pp. 326-348). London: Penguin.

Foucault, M. (2002c). 'Space, knowledge, and power. In P. Faubion (Eds.), Essential works of Foucault, 1954-1984, volume 3: Power (pp. 349-364). London: Penguin.

Foucault, M. (2003). Society must be defended: Lectures at the Collège de France 1975-1976. Basingstoke: Palgrave Macmillan.

Foucault, M. (2006). Psychiatric power: Lectures at the Collège de France 1973-1974. Basingstoke: Palgrave Macmillan.

Foucault, M. (2007). Security, territory, population: Lectures at the Collège de France 1977-1978. Basingstoke: Palgrave Macmillan.

Foucault, M. (2010). The birth of biopolitics: Lectures at the Collège de France 1978-1979. Basingstoke: Palgrave Macmillan.

Friedmann, J., \& Wolff, G. (1982). World city formation: An agenda for research and action. International Journal of Urban and Regional Research, 6(3), 309-344.

Geddes, P. (1915). Cities in evolution: An introduction to the town planning movement and to the study of civics. London: Williams \& Norgate.

George, S. (2010). Converging crises: Reality, fear and hope. Globalizations, 7(1-2), 17-22. 
Glucksberg, L. (2016). A view from the top: Unpacking capital flows and foreign investment in prime London. City, 20(2), 238-255.

Graham, S. (2010). Cities under siege: The new military urbanism. London: Verso.

Harvey, D. (1996). Cities or urbanization? City, 1(1-2), 38-61.

Harvey, D. (2003). The new imperialism. Oxford: Oxford University Press.

Harvey, D. (2006). Limits to capital. Oxford: Blackwell.

Harvey, D. (2010a). The enigma of capital, and the crisis of capitalism. Oxford: Oxford University Press.

Harvey, D. (2010b). A companion to capital. New York: Verso.

Harvey, D. (2013). Rebel cities: From the right to the city to the urban revolution. New York: Verso.

Harvey, D. (2015). Seventeen contradiction and the end of capitalism. London: Profile Books.

Herbst, J. (2014). States and power in Africa: Comparative lessons in authority and control. Princeton, NJ: Princeton University Press.

Horkheimer, M. (1985). The authoritarian state. In A. Arato \& E. Gebhardt (Eds.), The essential Frankfurt school reader (pp. 95-117). New York: Continuum.

Kaplan, R. D. (2012). The revenge of geography. New York: Random House.

Landes, D. (1999). The wealth and poverty of nations. New York: Abacus.

Lazzarato, M. (2015). Governing by debt. Los Angeles: Semiotext(e).

Lefebvre, H. (1973). The survival of capitalism: Reproduction of the relations of production. Oxford: Blackwell.

Lefebvre, H. (1991). The production of space. Oxford: Blackwell.

Lefebvre, H. (2009). State, space, world: Selected essays. Minneapolis, MN: University of Minnesota Press.

London, M. (2015). Housing in London 2015: The evidence base for the mayor's housing strategy. London: Greater London Authority.

Long, N. (1972). The unwalled city: Reconstituting the urban community. New York: Basic Books.

Lordon, F. (2014). Willing slaves of capital: Spinoza \& Marx on desire. New York: Verso.

Lowe, D. (1982). History of bourgeois perception. Chicago, IL: University of Chicago Press.

McFarlane, C. (2011a). Assemblage and critical urbanism. City, 15(2), 204-224.

McFarlane, C. (2011b). On context: Assemblage, political economy and structure. City, 15(3-4), 375388.

McFarlane, C. (2011c). The city as assemblage: Dwelling and urban space. Environment and Planning D: Society and Space, 29(4), 649-671.

McMichael, P. (2012). The land grab and corporate food regime restructuring. The Journal of Peasant Studies, 39(3-4), 681-701.

Merrifield, A. (2006). Henri lefebvre: A critical introduction. London: Routledge.

Minton, A. (2012). Ground control: Fear and happiness in the twenty-first-century city. London: Penguin.

Moore, J. W. (2015). Capitalism in the web of life: Ecology and the accumulation of capital. New York: Verso.

Mumford, L. (1955). Technics and civilization. London: Routledge \& Keegan Paul.

Nickerson, J. (2016, May 12). Mayor of London Sadiq Khan welcomes more armed police in London. City A.M. Online.

Panitch, L., \& Gindin, S. (2011). Capitalist crises and the crisis this time. Socialist Register, 47, 1-20.

Rancière, J. (1999). Disagreement: Politics and philosophy. Minneapolis, MN: University of Minnesota Press.

Rancière, J. (2012). The intellectual and his people: Staging the people, volume 2. London: Verso.

Rancière, J. (2014). The hatred of democracy. London: Verso.

Rancière, J. (2015). Dissensus. London: Bloomsbury.

Ruggie, J. G. (1993). Territoriality and beyond: Problematizing modernity in international relations. International Organization, 47(1), 139-174.

Sassen, S. (2001). The global city: New York, London, Tokyo. Princeton, NJ: Princeton University Press. Sassen, S. (2002). Global networks, linked cities. London: Routledge.

Sharpe, W., \& Wallock, L. (1987). From "great town" to "nonplace urban realm": reading the modern city. In W. Sharpe, \& L. Wallock (Eds.), Visions of the modern city: Essays in history, art, and literature (pp. 1-50). Baltimore, MD: Johns Hopkins University Press. 
Smith, N. (2007). Nature as accumulation strategy. Socialist Register, 43, 1-21.

Streeck, W. (2011). The crisis of democratic capitalism. New Left Review, II/71, 5-29.

Streeck, W. (2014). How will capitalism end? New Left Review, 87(1), 35-64.

Streeck, W. (2016). How will capitalism end? New York: Verso.

UNFPA. (2007). State of the world population 2007. Retrieved from https://www.unfpa.org/sites/ default/files/pub-pdf/695_filename_sowp2007_eng.pdf

United Nations, Department of Economic and Social Affairs, Population Division. (2014). World Urbanization Prospects: The 2014 Revision, Highlights (ST/ESA/SER.A/352). Retrieved from https:// esa.un.org/unpd/wup/publications/files/wup2014-highlights.Pdf

Virilio, P. (2006). Speed and politics: An essay on dromology. Los Angeles: Semiotext(e).

Watt, P. (2016). A nomadic war machine in the metropolis. City, 20(2), 297-320.

Watt, P., \& Minton, A. (2016). London's housing crisis and its activisms. City, 20(2), 204-221.

Weizman, E. (2006). Lethal theory. Log, 7, 53-77.

Welsh, J. (2016). The meta-disciplinary: Capital at the threshold of control. Critical Sociology [Online First].

Wilkinson, R. (2016, April 1). David Cameron announces hundreds more armed police to combat British terror threat in wake of Paris attacks. The Independent Online.

Zizek, S. (2008). Violence: Six sideways reflections. New York: Verso.

Zizek, S. (2010). Living in the end times. New York: Verso.

Zizek, S. (2012a). The revolt of the salaried bourgeoisie. London Review of Books, 34(2), 9-10.

Zizek, S. (2012b). The spectre of ideology. In S. Zizek (Ed.), Mapping ideology (pp. 1-33). London: Verso. 